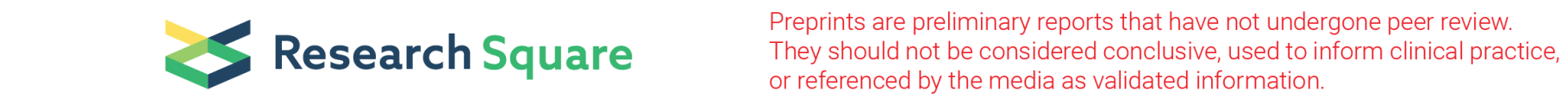

\title{
Serum Ghrelin in Mild Cognitive Impairment and Alzheimer's Disease A Systematic Review and Meta-analysis
}

\author{
Xiaodong Chen \\ Nanchang University Medical College: Medical College of Nanchang University \\ Yunfeng Luo ( $\square$ lyf008cn@qq.com ) \\ Affiliated Eye Hospital of Nanchang University https://orcid.org/0000-0002-2503-3517
}

\section{Research Article}

Keywords: ghrelin, acylated ghrelin, Alzheimer's disease, Mild cognitive impairment, systematic review, meta-analysis

Posted Date: May 14th, 2021

DOI: https://doi.org/10.21203/rs.3.rs-490560/v1

License: @ (i) This work is licensed under a Creative Commons Attribution 4.0 International License. Read Full License 


\section{Abstract \\ Background}

Serum ghrelin levels have been reported to be altered in Alzheimer's disease (AD) patients and individuals with Mild cognitive impairment $(\mathrm{MCl})$. However, whether serum ghrelin can be used as a biomarker of $A D$ is inconsistent and conflicting.

\section{Methods}

We carried out a systematic review and meta-analysis to examine the serum levels of ghrelin and acylated ghrelin (AG) in patients with $\mathrm{AD}$ or $\mathrm{MCl}$, in comparison with normal controls (NC). We searched PubMed, The Cochrane Library, Web of Science and Chinese National Knowledge Infrastructure (CNKI) from 1999 to March 2021.

\section{Results}

10 relevant studies were included for this study. 8 studies reported serum levels of ghrelin ( $417 \mathrm{AD}$ or $\mathrm{MCl}$ patients and 382 controls) and 5 studies reported serum levels of $A G(142 \mathrm{AD}$ or $\mathrm{MCl}$ patients and 152 controls). We found that $A D$ and $\mathrm{MCl}$ patients had a tendency toward a decrease in the serum levels of ghrelin $\left(S M D=-1.04 ; 95 \% \mathrm{Cl}(-2.30,0.23) ; \mathrm{P}=0.11\right.$; significant heterogeneity: $\left.I^{2}=98 \%\right)$, but no statistical significance was found. $A G$ levels in the serum level of $A D$ and $M C l$ patients were significantly higher than NC subjects $\left(\mathrm{SMD}=0.99 ; 95 \% \mathrm{Cl}(0.21,1.77) ; \mathrm{P}=0.01\right.$; significant heterogeneity: $\left.\mathrm{I}^{2}=87 \%\right)$.

\section{Conclusion}

This meta-analysis suggested that $\mathrm{AG}$ may be a potential $\mathrm{MCl}$ or early $\mathrm{AD}$ biomarker and confirmed previous findings that ghrelin became desensitized in AD patients. This meta-analysis was limited to small sample sizes and lacked of stratifying the level of heterogeneity in $\mathrm{AD}$ and $\mathrm{MCl}$ patients. More and large sample, multi-center case-control studies on the relationship between serum AG and $\mathrm{AD}$ or $\mathrm{MCl}$ patients are still needed in the future.

\section{Introduction}

Alzheimer's disease (AD) is a chronic progressive neurodegenerative disease characterized by memory decline and impaired cognitive function, which is the most common cause of dementia in the elderly (Querfurth and LaFerla 2010). The core pathological signs of $A D$ are amyloid- $\beta$ (A $\beta$ ) plaque deposition and neurofibrillary tangles (NFTs) containing Tau protein, accompanied by microglia proliferation(Long and Holtzman 2019). Though AD was usually considered a cognitive disorder and almost all people diagnosed with AD developing neuropsychiatric symptoms (NPS) at some stage during their disease(Lyketsos et al. 2011), the appetite and weight loss in $A D$ patients were reported and can be remarkable(Alzheimer et al. 1995). More than 80 percentage of patients with advanced dementia were observed appetite loss or dietary behavior disorders, which related with high mortality rates(Mitchell et al. 2009). Mild cognitive impairment $(\mathrm{MCl})$ was generally considered to be the predementia transition period of $A D$ (Albert et al. 2011).

Currently acetylcholinesterase (AChE) inhibitor and N-methyl D-aspartate (NMDA) receptor antagonists are the only treatments for AD approved by the Food and Drug Administration (FDA) of the United States, and both only can delay the clinical progression of $A D$ (Rountree et al. 2009). Therefore, identifying the risk factors for $A D$ is important for effectively preventing or postponing the onset of $\mathrm{AD}$ and $\mathrm{MCl}($ Crous-Bou et al. 2017).

Ghrelin is a peptide containing 28 amino acids synthesized and secreted by the oxyntic glands of the gastric fundus mucosa(Kojima et al. 1999), which is an endogenous ligand for the $G$ protein coupled receptor which called the growth hormone secretagogue receptor type 1a (GHS-R1a)(Date et al. 2000). A small amount of ghrelin mRNA expression has also been detected in the intestine, pancreas(Date et al. 2002), kidney(Tortorella et al. 2003), and placenta(Gualillo et al. 2001). The human ghrelin gene encodes a precursor peptide preproghrelin containing 117 amino acids, which is cleaved into proghrelin. Proghrelin is further enzymatically processed by prohormone convertase $1 / 3$ of proghrelin to form deacylated ghrelin (des acyl-ghrelin or DAG) and acylated ghrelin (acylghrelin or AG)(Zhu et al. 2006). DAG is converted to AG by post-translational acylation by Ghrelin 0-acyltransferase (GOAT)(Yang et al. 2008). Although DAG accounts for $90 \%$ of total Ghrelin (TG) in serum (Ariyasu et al. 2001), DAG does not bind to GHS-R1a, and its 
receptor is still unknown but has been postulated as CD36(Yanagi et al. 2018). Interestingly, DAG has been reported that might interfere with fibrillar amyloid- $\beta$ ( $f A \beta$ ) of activation of CD36 in N9 microglia cell, which do not express GHS-R1. The truncated ghrelin receptor polypeptide (GHS-R1 $\beta$ ), which is truncated by GHS-R1a, is not capable of combining with AG. GHS-R1 $\beta$ is considered to have a dominant-negative effect on ghrelin signaling by heterodimerization with GHS-R1a(Leung et al. 2007).

Ghrelin can increase the density of synaptic dendritic spines in the hippocampus and promote the formation of long-term potentiation (LTP)(Diano et al. 2006). Local infusion of ghrelin can enhance hippocampal synaptic plasticity and memory in rodents(Chen et al. 2011). Ghrelin directly stimulates adult hippocampal neurogenesis(Li et al. 2013). Numerous studies have reported that ghrelin(Eslami, Sadeghi, and Goshadrou 2018) and ghrelin agonists(Jeong et al. 2018) alleviated AD-related pathogenesis in animal models.

For clinical studies involving patients with $A D$ and $\mathrm{MCl}$, the investigation of the serum levels of ghrelin remains a controversial topic. While there have been various studies that reported lower serum ghrelin levels in patients with $A D$ and $\mathrm{MCl}$ when compared to normal controls, there were studies that reported results in the opposite direction. Here, following the inclusion-exclusion criteria precisely and adding the studies that have been published from 1999 up to April 2021, we designed a system review and meta-analysis to study the association of serum ghrelin levels with $\mathrm{AD}$ and $\mathrm{MCl}$.

\section{Methods}

Search strategy and study selection

We conducted this meta-analysis according to the recommended guidelines of the Preferred Reporting Items for Systematic Reviews and Meta-Analyses statement(Shamseer et al. 2015). The study protocol was registered with the International Prospective Register of Systematic Reviews. Computer searched for related literatures in PubMed, The Cochrane Library, Web of Science and Chinese National Knowledge Infrastructure (CNKI). The retrieval time is from 1999 to April 2021. Language was no limitation. Search terms were ("Alzheimer's Disease" OR "mild cognitive impairment") and "ghrelin".

To be included into this meta-analysis, studies must satisfy the following inclusion criteria: 1) case control or cross-section studies; 2) studies that provided a sample size and serum ghrelin or AG levels in at least two groups of subjects (AD, $\mathrm{MCl}$ and $\mathrm{NC})$; 3 ) Exclusion criteria included: (1) studies without the mean nor median serum ghrelin levels; (2) studies without NC; (3) case reports or case-only studies; (4) in vitro or laboratory studies; (5) AD or MCl patients with other diseases.

\section{Data extraction and quality assessment}

Two investigators independently assessed the included studies and extracted the relevant information from the literature, including the last name of first author, year of publication, diagnostic criteria for $A D$ or $\mathrm{MCl}$, sample size, mean age, gender ratio, serum collection protocol, serum analysis protocol, $A D$ or $\mathrm{MCl}$ diagnosis criteria, diagnosis, serum ghrelin levels, serum $A G$ levels. If study did not provide the $A D$ or $\mathrm{MCl}$ severity, we evaluated the severity according to the Mini-Mental State Examination (MMSE): mild, moderate, and severe dementia is defined as 21 to 26,10 to 20 , and 0 to 9 , respectively.

Two investigators assessed methodological quality independently according to the QUADAS (Quality Assessment of Diagnostic Accuracy Studies) criteria(Whiting et al. 2003). The value of SMD was used to compare the difference between patients with $A D$ or MCI and NC. 6 items concerned with reference standard were excluded. The remaining 8 items were used to assess the study quality, including representative spectrum of disease, definition of study criteria, disease progress bias avoid, partial verification bias avoid, detailed description of test, availability of data, uninterpretable results reported, withdrawals explained. Each item was assessed with "Yes," "No," or "unclear". The answer of "Yes" indicated no risk bias, "No" for high-risk bias and "unclear" for not clear risk bias.

\section{Data synthesis and statistical analyses}

Meta-analyses were performed using RevMan5.3 following the Cochrane Manual for Systematic Evaluation of Interventions. The $\mathrm{I}^{2}$ statistic was used to examine the heterogeneity. No heterogeneity: $I^{2}=0 \%$, low heterogeneity: $I^{2}=25 \%$, moderate heterogeneity: $I^{2}=$ $50 \%$, and $\mathrm{I}^{2}=75 \%$ suggests high heterogeneity. A fixed effects model was used when no statistical heterogeneity was detected $(P>0.1$, and $\mathrm{I}^{2}<50 \%$ ); otherwise, a random effects model was used. Standardized Mean Difference (SMD), which expresses the difference in mean for the individual study, was used as the summary statistic. Subgroup analysis and sensitivity analysis were used to explain the high heterogeneity 
For several studies with only median and interquartile ranges available in the manuscripts, estimations of the means and standard deviations were performed according to Wan et al(Wan et al. 2014). Calculate the baseline, change and the final in the original data through the Cochrane Handbook. Publication bias was determined using Egger's tests by using the package metafor within the statistical programming language R. Significance was set at a P value less than 0.05 .

\section{Results}

\section{Literature search}

A total of 214 potential articles were found through the computerized databases search, one study was found through other sources. 51 articles were excluded due to duplication. After reviewing the title and abstract of every article, 163 articles were excluded because of exclusion criteria. Full-text evaluation were conducted in the remaining 16 studies, 6 articles were excluded for lack of the standard of study selection. Finally, 10 studies met our inclusion criteria for meta-analysis. The flow diagram of the systematic literature review is presented in Fig 1.

\section{Study characteristics}

Publication years of 10 studies all ranged from 2006 to 2019. 8 studies reported serum levels of ghrelin (417 AD or MCl patients and 382 controls) and 5 studies reported serum levels of $\mathrm{AG}(142 \mathrm{AD}$ or $\mathrm{MCl}$ patients and 152 controls). The subjects of one study was $\mathrm{MCl}$ patients(Cao et al. 2018), and one study was MCl or early AD patients(Monte et al. 2019), the remaining 8 studies are all for AD patients. A study reported the serum AG and DAG levels separately in AD patients(Yoshino et al. 2018). The combined results were calculated using equation 5.38 from Statistical Simulation: Power Method Polynomials and other Transformations (Demirtas 2011). Each study contains a clear guideline for the diagnosis of AD patients. The methods for ghrelin and AG detection included enzymelinked immunosorbent assay (ELISA), radioimmunoassay (RIA), High Performance Liquid Chromatography-Mass Spectrometry (HPLCMS). The summary of included studies is presented in Table 1.

The results of the methodological assessment for review are summarized in Table 2.

\section{Ghrelin and $A D / M C l$}

The random effect model was used for this meta-analysis. In the meta-analysis, Meta-analysis of those 8 studies showed that AD and $\mathrm{MCl}$ patients tended to have lower serum ghrelin levels compared with $\mathrm{NC}$ subjects $(\mathrm{SMD}=-1.04 ; 95 \% \mathrm{Cl}(-2.30,0.23)$; $\mathrm{P}=0.11$; significant heterogeneity: $I^{2}=98 \%$ ) (Fig. 2), but there was no significantly statistical difference. Based on egger's test, there was no publication bias in the serum ghrelin levels between the patients with $A D / M C l$ and $N C$ (intercept $=0.36, p=0.735$ ). Subgroup analysis was used to explain reason of high heterogeneity. According to differences of site of studies, 8 studies were classified by Chinese and Non-Chinese studies. The results showed that 3 studies came from China $\left(I^{2}=99 \%, P=0.04\right)$ and Non-China $\left(I^{2}=0 \%, P=0.25\right)($ Fig. 3).

\section{$A G$ and $A D / M C l$}

The random effect model was used because of high heterogeneity $\left(I^{2}=87 \%\right)$. High serum AG levels were significantly associated with increased risk of $A D / M C l$ compared with low $A G$ levels in 5 studies $\left(S M D=0.99 ; 95 \% \mathrm{Cl}(0.21,1.77) ; P=0.01\right.$; significant heterogeneity: $I^{2}$ $=87 \%$ ) (Fig. 4). Based on egger's test, there was no publication bias in the serum ghrelin levels between the patients with $A D / M C l$ and $N C$ (intercept $=1.76, p=0.176$ ). Sensitivity analysis was used to explain reason of high heterogeneity. After excluding two studies with $\mathrm{MCl}$ or early $\mathrm{AD} / \mathrm{MCI}\left(\right.$ Monte et al. 2019), the remaining studies with moderate $A D$ show low heterogeneity $\left(I^{2}=29 \%\right)$, and std. mean difference was $0.41(95 \% \mathrm{Cl}(0.02,0.80) ; \mathrm{P}=0.04)$.

\section{Discussion}

To date, the association of serum ghrelin levels with $A D$ and $\mathrm{MCl}$ remains controversial. This meta-analysis compared the serum levels of ghrelin in patients with $A D$, individuals with $\mathrm{MCl}$, and normal controls. We concluded that $A D$ and $\mathrm{MCl}$ patients tended to have lower serum ghrelin levels compared with $\mathrm{NC}$ subjects $\left(\mathrm{SMD}=-1.04 ; 95 \% \mathrm{Cl}(-2.30,0.23) ; \mathrm{P}=0.11\right.$; significant heterogeneity: $\left.\mathrm{I}^{2}=98 \%\right)$, but no statistical significance was found. The pathogenesis and clinical manifestations of AD were highly heterogeneous(Dujardin et al. 2020). However, limited by small sample, we failed to stratify the level of heterogeneity in AD and MCI patients. 
Strikingly, this meta-analysis found the AG levels in the serum of $A D$ and $\mathrm{MCl}$ patients were significantly higher than NC subjects $\left(S M D=0.99 ; 95 \% \mathrm{Cl}(0.21,1.77) ; P=0.01\right.$; significant heterogeneity: $\left.\mathrm{I}^{2}=87 \%\right)$. Besides, the increase of serum $\mathrm{AG}$ in $\mathrm{MCl} /$ early $A D$ patients was much higher than patients with moderate $A D$ by using sensitivity analysis. This indicate that $A G$ may be a potential early biomarker for patients with $\mathrm{AD}$ and $\mathrm{MCl}$.

Previous studies found that mRNA expression of GHS-R1 a were decreased in the plasma(Yoshino et al. 2018) and the temporal lobe(Gahete et al. 2010) of AD patients. In contrast, mRNA levels of the GHS-R1a-trapping GHS-R1b were significantly increased, which indicated that ghrelin become desensitized in AD patients. We speculated that the increase of GHS-R1b in the pathological process of $A D$ leads to the decrease of GHS-R1a that can be combined with AG. Due to the desensitization of ghrelin in AD and MCl patients, AG was produced to compete with GHS-R1b for GHS-R1a. Interestingly, GHS-R1b was reported to not only determine the function of AGGHS-R1a signaling, but also determine the capacity of GHS-R1a to combine with other receptors to oligomerize(Navarro et al. 2016). Though some studies have reported the mechanism by which GHS-R1b affects ghrelin signaling, no study reported the role of GHS-R1b in the progression of AD. Interestingly, the truncated-GHSR1b was considered to promote progression of certain endocrine-related cancers(Luque et al. 2015). Compare to the ineffectiveness of GHS-R1a agonist MK-0677 on AD progression in a randomized clinical trial(Sevigny et al. 2008), this study indicated that the inhibition of GHS-R1b may be a potential and effective therapy for $A D$ and $\mathrm{MCl}$ patients.

In general, this meta-analysis analyzed the relationship between serum ghrelin and $A G$ and $A D$ and $\mathrm{MCl}$ patients in the current casecontrol study, filled the gap in data analysis of serum ghrelin and $A G$ levels in $A D$ and $M C l$ patients, and proposed $A G$ as a potential $M C l$ or early $A D$ biomarker. High heterogeneity was found in our meta-analysis, which could be mostly due to the severity of $A D$ and site of studies. Future study can focus on the mechanism of the increase of GHS-R1a- trapping GHS-R1b in AD and MCI patients and the feasibility of GHS-R1b inhibitors in the treatment of $A D$ and $\mathrm{MCl}$. However, limited by the small sample size and the lack of stratifying the level of heterogeneity in $A D$ and $\mathrm{MCl}$ patients, more and large sample, multi-center case-control studies on the relationship between serum $A G$ and $A D$ and $M C l$ are still needed in the future.

\section{Declarations}

\section{Funding information}

This work was funded by grants from the National Natural Science Foundation of China (Yunfeng Luo, No. 81760239) and Natural Science Foundation of Jiangxi Province (Yunfeng Luo, No. 20202BABL206063).

\section{Conflict of Interest}

The authors have no conflict of interest to report.

\section{Contributions}

All authors contributed to the study conception and design. Material preparation, data collection and analysis were performed by Xiaodong Chen and Yunfeng Luo. The first draft of the manuscript was written by Xiaodong Chen and all authors commented on previous versions of the manuscript. All authors read and approved the final manuscript.

\section{References}

Ahmed, R. M., S. Latheef, L. Bartley, M. Irish, G. M. Halliday, M. C. Kiernan, J. R. Hodges, and O. Piguet. 2015. 'Eating behavior in frontotemporal dementia: Peripheral hormones vs hypothalamic pathology', Neurology, 85: 1310-7.

Albert, M. S., S. T. DeKosky, D. Dickson, B. Dubois, H. H. Feldman, N. C. Fox, A. Gamst, D. M. Holtzman, W. J. Jagust, R. C. Petersen, P. J. Snyder, M. C. Carrillo, B. Thies, and C. H. Phelps. 2011. 'The diagnosis of mild cognitive impairment due to Alzheimer's disease: recommendations from the National Institute on Aging-Alzheimer's Association workgroups on diagnostic guidelines for Alzheimer's disease', Alzheimers Dement, 7: 270-9.

Alzheimer, A., R. A. Stelzmann, H. N. Schnitzlein, and F. R. Murtagh. 1995. 'An English translation of Alzheimer's 1907 paper, "Uber eine eigenartige Erkankung der Hirnrinde"', Clinical Anatomy, 8: 429-31.

Page 5/11 
Ariyasu, H., K. Takaya, T. Tagami, Y. Ogawa, K. Hosoda, T. Akamizu, M. Suda, T. Koh, K. Natsui, S. Toyooka, G. Shirakami, T. Usui, A. Shimatsu, K. Doi, H. Hosoda, M. Kojima, K. Kangawa, and K. Nakao. 2001. 'Stomach is a major source of circulating ghrelin, and feeding state determines plasma ghrelin-like immunoreactivity levels in humans', J Clin Endocrinol Metab, 86: 4753-8.

Cao, X., M. Zhu, Y. He, W. Chu, Y. Du, and H. Du. 2018. 'Increased Serum Acylated Ghrelin Levels in Patients with Mild Cognitive Impairment', J Alzheimers Dis, 61: 545-52.

Chen, L., T. Xing, M. Wang, Y. Miao, M. Tang, J. Chen, G. Li, and D. Y. Ruan. 2011. 'Local infusion of ghrelin enhanced hippocampal synaptic plasticity and spatial memory through activation of phosphoinositide 3-kinase in the dentate gyrus of adult rats', Eur $J$ Neurosci, 33: 266-75.

Crous-Bou, M., C. Minguillón, N. Gramunt, and J. L. Molinuevo. 2017. 'Alzheimer's disease prevention: from risk factors to early intervention', Alzheimer's Research \& Therapy, 9: 71.

Date, Y., M. Kojima, H. Hosoda, A. Sawaguchi, M. S. Mondal, T. Suganuma, S. Matsukura, K. Kangawa, and M. Nakazato. 2000. 'Ghrelin, a novel growth hormone-releasing acylated peptide, is synthesized in a distinct endocrine cell type in the gastrointestinal tracts of rats and humans', Endocrinology, 141: 4255-61.

Date, Y., M. Nakazato, S. Hashiguchi, K. Dezaki, M. S. Mondal, H. Hosoda, M. Kojima, K. Kangawa, T. Arima, H. Matsuo, T. Yada, and S. Matsukura. 2002. 'Ghrelin is present in pancreatic alpha-cells of humans and rats and stimulates insulin secretion', Diabetes, 51: 124-9.

Demirtas, Hakan. 2011. 'Statistical Simulation: Power Method Polynomials and Other Transformations', $2011,43: 3$.

Diano, S., S. A. Farr, S. C. Benoit, E. C. McNay, I. da Silva, B. Horvath, F. S. Gaskin, N. Nonaka, L. B. Jaeger, W. A. Banks, J. E. Morley, S. Pinto, R. S. Sherwin, L. Xu, K. A. Yamada, M. W. Sleeman, M. H. Tschöp, and T. L. Horvath. 2006. 'Ghrelin controls hippocampal spine synapse density and memory performance', Nat Neurosci, 9: 381-8.

Dujardin, S., C. Commins, A. Lathuiliere, P. Beerepoot, A. R. Fernandes, T. V. Kamath, M. B. De Los Santos, N. Klickstein, D. L. Corjuc, B. T. Corjuc, P. M. Dooley, A. Viode, D. H. Oakley, B. D. Moore, K. Mullin, D. Jean-Gilles, R. Clark, K. Atchison, R. Moore, L. B. Chibnik, R. E. Tanzi, M. P. Frosch, A. Serrano-Pozo, F. Elwood, J. A. Steen, M. E. Kennedy, and B. T. Hyman. 2020. 'Tau molecular diversity contributes to clinical heterogeneity in Alzheimer's disease', Nat Med, 26: 1256-63.

Eslami, Maryam, Bahman Sadeghi, and Fatemeh Goshadrou. 2018. 'Chronic ghrelin administration restores hippocampal long-term potentiation and ameliorates memory impairment in rat model of Alzheimer's disease', Hippocampus, 28.

Gahete, M. D., A. Rubio, J. Córdoba-Chacón, F. Gracia-Navarro, R. D. Kineman, J. Avila, R. M. Luque, and J. P. Castaño. 2010. 'Expression of the ghrelin and neurotensin systems is altered in the temporal lobe of Alzheimer's disease patients', J Alzheimers Dis, $22: 819-28$.

Gualillo, O., J. Caminos, M. Blanco, T. Garcia-Caballero, M. Kojima, K. Kangawa, C. Dieguez, and F. Casanueva. 2001. 'Ghrelin, a novel placental-derived hormone', Endocrinology, 142: 788-94.

Huang, Che. 2019. 'The channels and functions of Ghrelin in the inflammatory factor regulation

among elderly patients with Alzheimer's disease', Chin J Convalescent Med, 28: 789-91.

Huang, Dongming, Hu Caiyou, Qin shaodong, Liang Qinghua, Li Sijun, Yang huadan, Chen Yingping, and Wang liwen. 2018. 'Ghrelin level and its relation with Toll-like receptor-4 signal pathway in patients with Alzheimer's disease', Guangxi Meidical Journal, 40: 114144.

Jeong, Y. O., S. J. Shin, J. Y. Park, B. K. Ku, J. S. Song, J. J. Kim, S. G. Jeon, S. M. Lee, and M. Moon. 2018. 'MK-0677, a Ghrelin Agonist, Alleviates Amyloid Beta-Related Pathology in 5XFAD Mice, an Animal Model of Alzheimer's Disease', Int J Mol Sci, 19.

Kojima, M., H. Hosoda, Y. Date, M. Nakazato, H. Matsuo, and K. Kangawa. 1999. 'Ghrelin is a growth-hormone-releasing acylated peptide from stomach', Nature, 402: 656-60.

Leung, P. K., K. B. Chow, P. N. Lau, K. M. Chu, C. B. Chan, C. H. Cheng, and H. Wise. 2007. 'The truncated ghrelin receptor polypeptide (GHS-R1b) acts as a dominant-negative mutant of the ghrelin receptor', Cellular Signalling, 19: 1011-22.

Page 6/11 
Li, E., H. Chung, Y. Kim, D. H. Kim, J. H. Ryu, T. Sato, M. Kojima, and S. Park. 2013. 'Ghrelin directly stimulates adult hippocampal neurogenesis: implications for learning and memory', Endocr J, 60: 781-9.

Long, J. M., and D. M. Holtzman. 2019. 'Alzheimer Disease: An Update on Pathobiology and Treatment Strategies', Cell, $179: 312-39$.

Luque, R. M., M. Sampedro-Nuñez, M. D. Gahete, A. Ramos-Levi, A. Ibáñez-Costa, E. Rivero-Cortés, A. Serrano-Somavilla, M. Adrados, M. D. Culler, J. P. Castaño, and M. Marazuela. 2015. 'In1-ghrelin, a splice variant of ghrelin gene, is associated with the evolution and aggressiveness of human neuroendocrine tumors: Evidence from clinical, cellular and molecular parameters', Oncotarget, 6: $19619-33$.

Lyketsos, C. G., M. C. Carrillo, J. M. Ryan, A. S. Khachaturian, P. Trzepacz, J. Amatniek, J. Cedarbaum, R. Brashear, and D. S. Miller. 2011. 'Neuropsychiatric symptoms in Alzheimer's disease', Alzheimers Dement, 7: 532-9.

Mitchell, S. L., J. M. Teno, D. K. Kiely, M. L. Shaffer, R. N. Jones, H. G. Prigerson, L. Volicer, J. L. Givens, and M. B. Hamel. 2009. 'The clinical course of advanced dementia', New England Journal of Medicine, 361: 1529-38.

Monte, Suzanne M. de la, Ming Tong, Lori A. Daiello, and Brian R. Ott. 2019. 'Early-Stage Alzheimer's Disease Is Associated with Simultaneous Systemic and Central Nervous System Dysregulation of Insulin-Linked Metabolic Pathways', J Alzheimers Dis, 68.

Navarro, G., D. Aguinaga, E. Angelats, M. Medrano, E. Moreno, J. Mallol, A. Cortés, E. I. Canela, V. Casadó, P. J. McCormick, C. Lluís, and S. Ferré. 2016. 'A Significant Role of the Truncated Ghrelin Receptor GHS-R1b in Ghrelin-induced Signaling in Neurons', Journal of Biological Chemistry, 291: 13048-62.

Proto, C., D. Romualdi, R. M. Cento, R. S. Spada, G. Di Mento, R. Ferri, and A. Lanzone. 2006. 'Plasma levels of neuropeptides in Alzheimer's disease', Gynecol Endocrinol, 22: 213-8.

Querfurth, H. W., and F. M. LaFerla. 2010. 'Alzheimer's disease', N Engl J Med, 362: 329-44.

Rountree, S. D., W. Chan, V. N. Pavlik, E. J. Darby, S. Siddiqui, and R. S. Doody. 2009. 'Persistent treatment with cholinesterase inhibitors and/or memantine slows clinical progression of Alzheimer disease', Alzheimers Res Ther, 1: 7.

Sevigny, J. J., J. M. Ryan, C. H. van Dyck, Y. Peng, C. R. Lines, and M. L. Nessly. 2008. 'Growth hormone secretagogue MK-677: no clinical effect on AD progression in a randomized trial', Neurology, 71: 1702-8.

Shamseer, L., D. Moher, M. Clarke, D. Ghersi, A. Liberati, M. Petticrew, P. Shekelle, and L. A. Stewart. 2015. 'Preferred reporting items for systematic review and meta-analysis protocols (PRISMA-P) 2015: elaboration and explanation', Bmj, 350 : g7647.

Theodoropoulou, A., I. C. Metallinos, A. Psyrogiannis, G. A. Vagenakis, and V. Kyriazopoulou. 2012. 'Ghrelin and leptin secretion in patients with moderate Alzheimer's disease', J Nutr Health Aging, 16: 472-7.

Torsello, A., E. Bresciani, M. Ravelli, L. Rizzi, I. Bulgarelli, G. Ricci, B. Ghiazza, M. Del Puppo, V. Mainini, R. J. Omeljaniuk, L. Tamiazzo, G. Mancia, F. Magni, and V. Locatelli. 2012. 'Novel domain-selective ACE-inhibiting activity of synthetic growth hormone secretagogues', Pharmacol Res, 66: 317-24.

Tortorella, C., C. Macchi, R. Spinazzi, L. K. Malendowicz, M. Trejter, and G. G. Nussdorfer. 2003. 'Ghrelin, an endogenous ligand for the growth hormone-secretagogue receptor, is expressed in the human adrenal cortex', Int J Mol Med, 12: 213-7.

Wan, X., W. Wang, J. Liu, and T. Tong. 2014. 'Estimating the sample mean and standard deviation from the sample size, median, range and/or interquartile range', BMC Med Res Methodol, 14: 135.

Whiting, P., A. W. Rutjes, J. B. Reitsma, P. M. Bossuyt, and J. Kleijnen. 2003. 'The development of QUADAS: a tool for the quality assessment of studies of diagnostic accuracy included in systematic reviews', BMC Medical Research Methodology, 3: 25.

Woolley, J. D., B. K. Khan, A. Natesan, A. Karydas, M. Dallman, P. Havel, B. L. Miller, and K. P. Rankin. 2014. 'Satiety-related hormonal dysregulation in behavioral variant frontotemporal dementia', Neurology, 82: 512-20.

Yanagi, S., T. Sato, K. Kangawa, and M. Nakazato. 2018. 'The Homeostatic Force of Ghrelin', Cell Metabolism, 27: 786-804. 
Yang, J., M. S. Brown, G. Liang, N. V. Grishin, and J. L. Goldstein. 2008. 'Identification of the acyltransferase that octanoylates ghrelin, an appetite-stimulating peptide hormone', Cell, 132: 387-96.

Yoshino, Y., Y. Funahashi, S. Nakata, Y. Ozaki, K. Yamazaki, T. Yoshida, T. Mori, Y. Mori, S. Ochi, J. Iga, and S. Ueno. 2018. 'Ghrelin cascade changes in the peripheral blood of Japanese patients with Alzheimer's disease', Journal of Psychiatric Research, 107: 79-85.

Zhu, X., Y. Cao, K. Voogd, and D. F. Steiner. 2006. 'On the processing of proghrelin to ghrelin', J Biol Chem, 281: 38867-70.

\section{Tables}

Table 1. Summary of the studies that are included in this analysis.

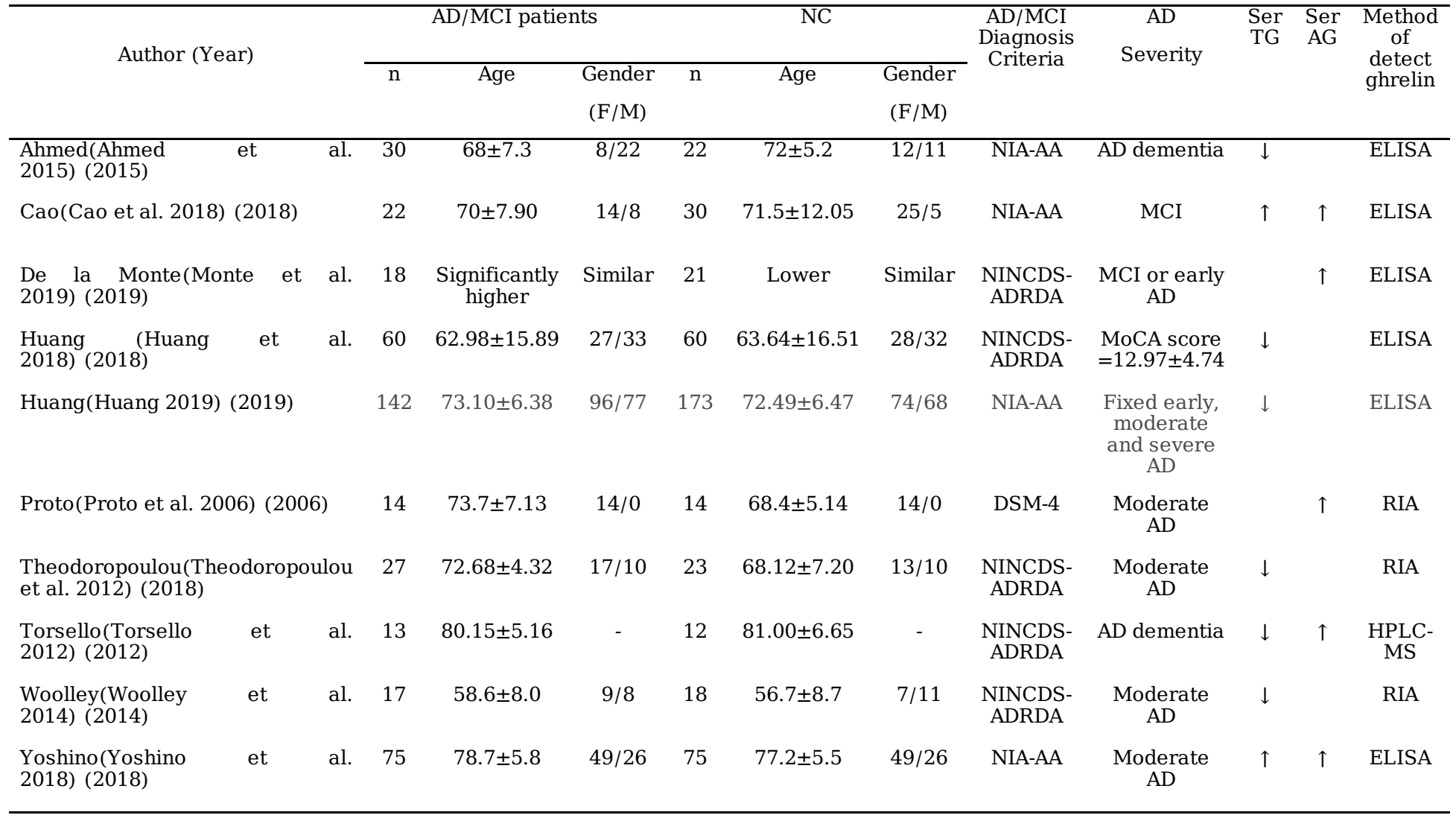

Table 2. Quality Assessment of Diagnostic Accuracy Studies (QUADAS) tool criteria fulfilled for the included studies. 


\begin{tabular}{|c|c|c|c|c|c|c|c|c|}
\hline Study & $\begin{array}{l}\text { Representative } \\
\text { spectrum of } \\
\text { disease }\end{array}$ & $\begin{array}{l}\text { Definition } \\
\text { of study } \\
\text { criteria }\end{array}$ & $\begin{array}{c}\text { Disease } \\
\text { progress } \\
\text { bias avoid }\end{array}$ & $\begin{array}{c}\text { Partial } \\
\text { verification } \\
\text { bias avoid }\end{array}$ & $\begin{array}{l}\text { Detailed } \\
\text { description } \\
\text { of test }\end{array}$ & $\begin{array}{l}\text { Availability } \\
\text { of data }\end{array}$ & $\begin{array}{l}\text { Uninterpretable } \\
\text { results } \\
\text { reported }\end{array}$ & $\begin{array}{c}\text { Withdrawals } \\
\text { explained }\end{array}$ \\
\hline Ahmed 2015 & $?$ & $\mathrm{Y}$ & $\mathrm{Y}$ & $\bar{Y}$ & $\mathrm{Y}$ & $?$ & $\mathrm{Y}$ & $\mathrm{Y}$ \\
\hline Саo 2018 & $\mathrm{Y}$ & $\mathrm{Y}$ & $\mathrm{Y}$ & $\mathrm{Y}$ & $\mathrm{Y}$ & $\mathrm{Y}$ & ? & $\mathrm{Y}$ \\
\hline $\begin{array}{l}\text { De la Monte } \\
2019\end{array}$ & $\mathrm{Y}$ & $\mathrm{Y}$ & $\mathrm{Y}$ & $\mathrm{Y}$ & $\mathrm{Y}$ & ? & $\mathrm{Y}$ & $\mathrm{Y}$ \\
\hline Huang 2018 & Y & Y & Y & $?$ & $\mathrm{Y}$ & $?$ & $?$ & Y \\
\hline Huang 2019 & ? & $\mathrm{Y}$ & $\mathrm{Y}$ & ? & $\mathrm{Y}$ & $\mathrm{Y}$ & ? & $\mathrm{Y}$ \\
\hline Proto 2006 & Y & Y & Y & Y & $\mathrm{Y}$ & Y & ? & Y \\
\hline $\begin{array}{l}\text { Theodoropoulou } \\
2018\end{array}$ & $\mathrm{Y}$ & $\mathrm{Y}$ & $\mathrm{Y}$ & $\mathrm{Y}$ & $\mathrm{Y}$ & ? & $\mathrm{Y}$ & $\mathrm{Y}$ \\
\hline Torsello 2012 & $?$ & $?$ & Y & Y & Y & Y & Y & Y \\
\hline Woolley 2014 & ? & ? & $\mathrm{Y}$ & $\mathrm{Y}$ & $\mathrm{Y}$ & $\mathrm{Y}$ & $\mathrm{Y}$ & $\mathrm{Y}$ \\
\hline Yoshino 2018 & $\mathrm{Y}$ & $\mathrm{Y}$ & $\mathrm{Y}$ & $\mathrm{Y}$ & $\mathrm{Y}$ & ? & ? & $\mathrm{Y}$ \\
\hline
\end{tabular}

Note: $\mathrm{Y}=$ Yes (No risk bias); ? = unclear risk bias; $\mathrm{N}=$ No (high risk of bias)

Abbreviations: AD, Alzheimer's Disease; AG, acylated ghrelin; ELISA, enzyme-linked immunosorbent assay; F, female; M, male; NC, normal control; RIA, radioimmunoassay; Ser, serum; TG, total ghrelin; DSM, Diagnostic and Statistical Manual of Mental Disorders; HPLC-MS, High Performance Liquid Chromatography-Mass Spectrometry; NIA-AA, National Institute on Aging/Alzheimer's Association NINCDS-ADRDA, National Institute of Neurological and Communicative Disorders and Stroke- Alzheimer's Disease and Related Disorders Association; MoCA, Montreal Cognitive Assessment

\section{Figures}


Records identified through PubMed,

Cochrane, Web of Science and CNKI $(\mathrm{n}=214)$

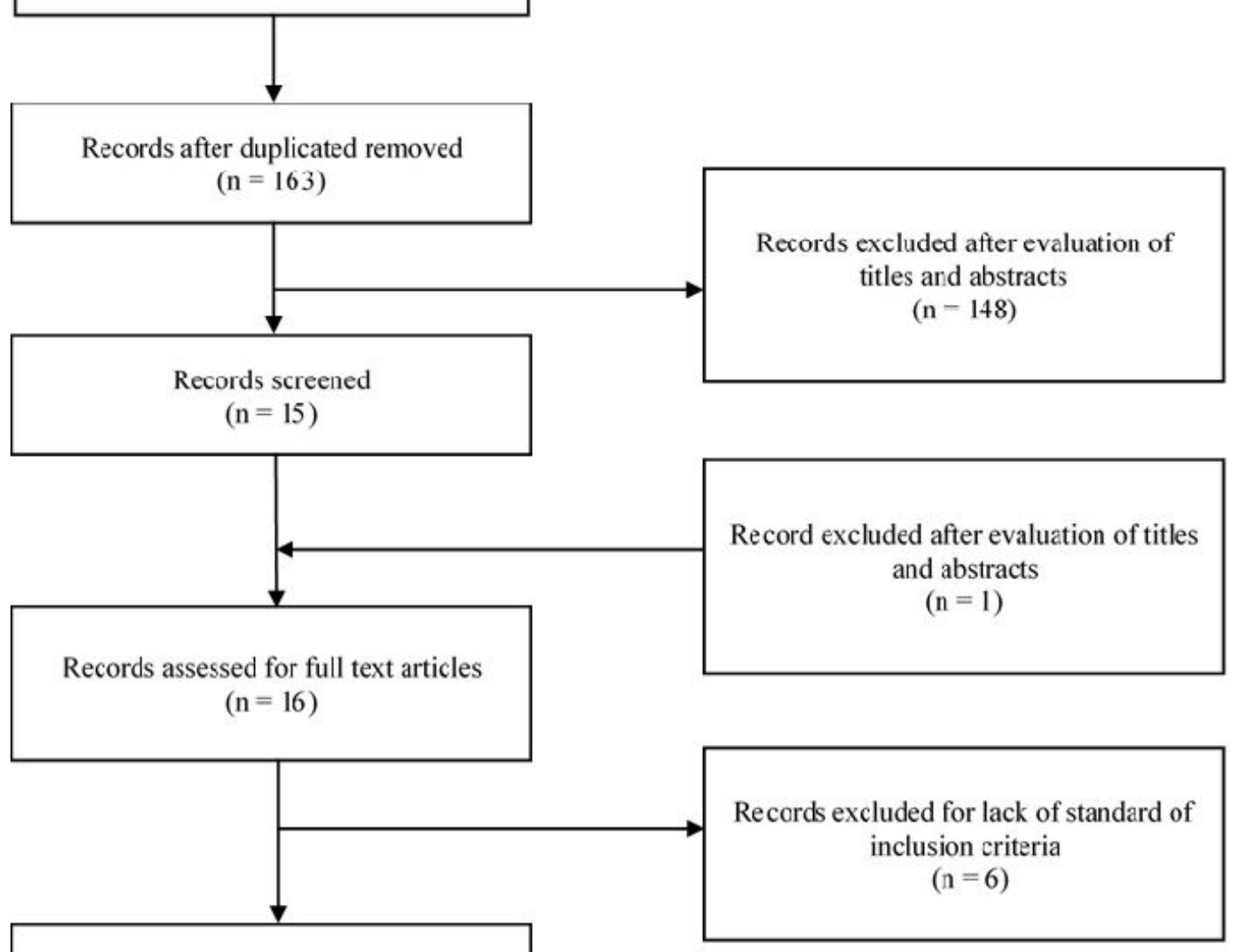

Studies included in meta-analysis

$(\mathrm{n}=10)$

Figure 1

PRISMA Flow Diagram for Study Selection.

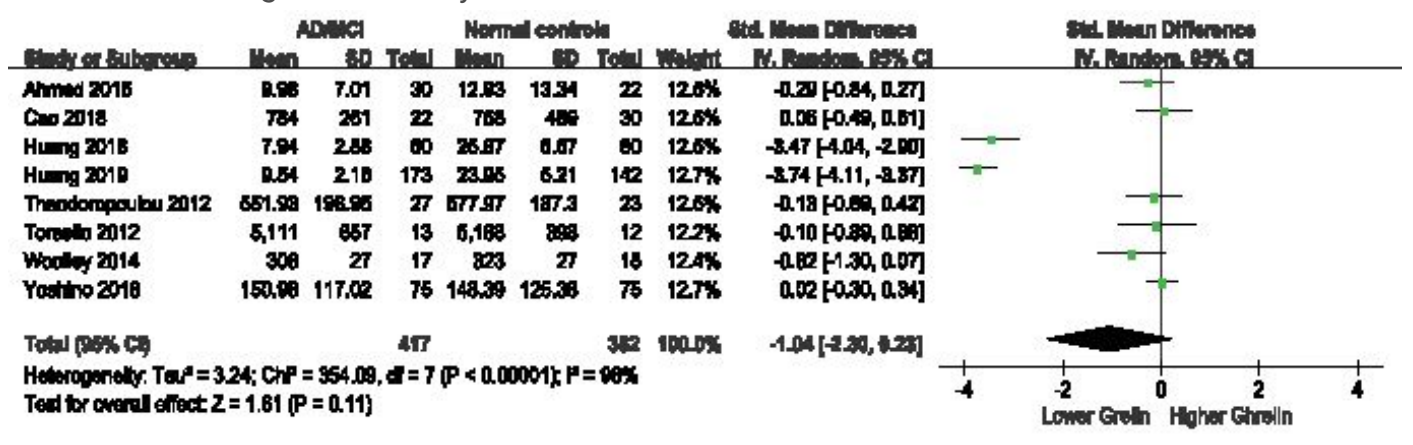

Figure 2

Meta-analyses for the difference of serum ghrelin levels between patients with $A D$ and $\mathrm{MCl}$ and normal controls. 


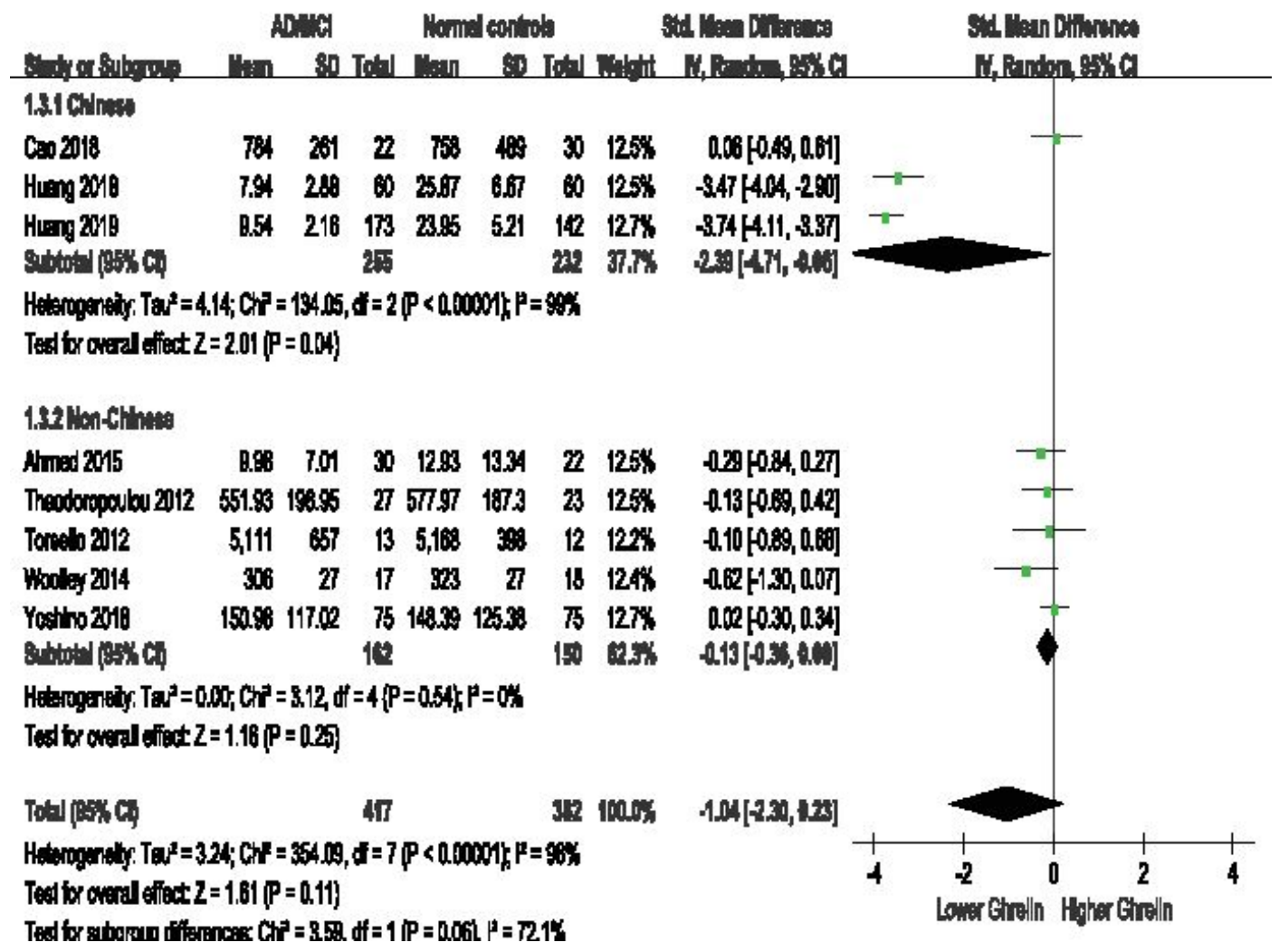

Figure 3

Subgroup Meta-analyses for the difference of serum ghrelin levels between patients with $\mathrm{AD}$ and $\mathrm{MCl}$ and normal controls.

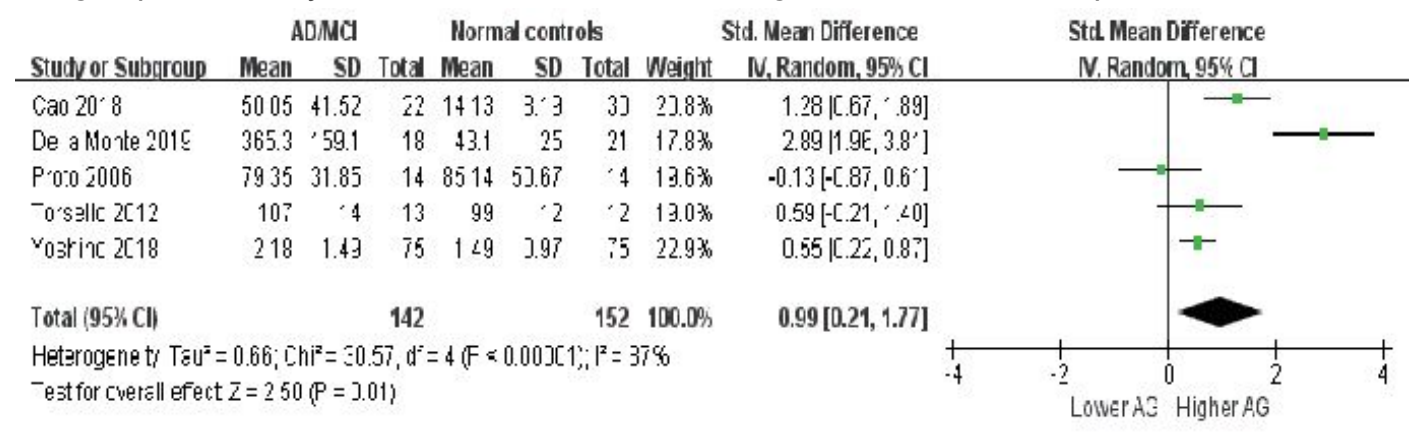

Figure 4

Meta-analyses for the difference of $A G$ levels between patients with $A D$ and $\mathrm{MCl}$ and normal controls. 